\title{
Potential of Eco-Efficiency Application to Small-To-Medium Industry of Tofu Cluster in Pesalakan, Adiwerna Village, Adiwerna District, Tegal Regency
}

\author{
Sri Suryoko ${ }^{1 *}$, Sudharto $P$ Hadi $^{1}$, and Purwanto ${ }^{1}$ \\ ${ }^{1}$ Doctoral Program of Environmental Science, School of Postgraduate Studies, Diponegoro University, Semarang - Indonesia,
}

\begin{abstract}
Tofu is a highly popular food in Indonesia. Its production process also has a high risk of environmental pollution. There were many and high capacities of tofu makers in the tofu clusters of Pesalakan, Adiwerna Village, Adiwerna District, Tegal Regency. Due to its high pollution risk, this industry needed an eco-efficiency analysis. Using cleaner production practices the good eco-efficiency potential might be achieved so that the environmental quality can be improved. This study collected data from informal interviews, field observation, and production process calculation. The cleaner production practices by boiling water in a cover pan by energy source resulted in the following efficiency rates: sawdust 31-37\% energy efficiency and 27-30\% time efficiency; and husk energy 35-57\% energy efficiency and 20.7-20.9\% time efficiency. The highest annual eco-efficiency rate for profit was Rp $1,194,251.01 /$ ton of $\mathrm{CO}_{2}$ equivalent/year, while the lowest rate was $\mathrm{Rp} 472,804.89 /$ ton $\mathrm{CO}_{2} /$ year. The small industry could never manage to practice the eco-efficiency without support from the government and the community.
\end{abstract}

Keywords: Cleaner production; eco-efficiency; small-to-medium enterprise.

\section{Introduction}

Industrial activities result in either positive or negative impacts. The positive ones include improving economic activities, which contributed to community welfare. Whereas, the negatives include air, water, and land pollution, which created inconvenience. The more negative impacts of the tofu industry have motivated large manufactures to decide to apply cleaner-production in their environmental technology [1]. The cleanerproduction practices have become among important preventive and sustainable strategies for processes, goods, and services towards improving efficiency and reducing risks on human and environment [1]. The most common preventive practices include product modification, which, in line with cleaner production development, gives rise to eco-efficiency. Eco-efficiency is a key concept that can help industries, individuals, government, and organizations to be more sustainable [2]. This concept is how efficient we make use of environmental resources to fulfill human needs [3].

Small-to-medium enterprises (SMEs) are among the economic pillars of Indonesia. In 2001 there were 49.8 million SMEs [4]. This figure increased by $21.06 \%$ in 2016, soaring the figure up to 60.29 million (Kompas, Wednesday, 17 February 2016) [5]. One of the popular SMEs in Indonesia is the tofu industry. In 1990 the country recorded 25,870 units, but there were only 63 of them $(0.24 \%)$ were large-to-medium. In other words, the small-to-medium units dominated the contest [6]. As a household-scale industry, tofu processing has a high potential of disturbing the environmental carrying capacity. Pollutions derived from the tofu industry include wastewater that contains BOD, COD, sulfide, and $\mathrm{pH}$, as well as exhaust emission [7].

Tofu products are resulted by the manufacturing process, an activity process classified as the dirty economic sector [8]. In terms of the agricultural industry, it is classified into light pollution [9]. However, several studies prove that pollution from small industries in the dirty economic sector is more intensive than their large counterparts [8]. The tofu industry in Tegal Regency is categorized as the household industry. There were approximately 1,200 tofu makers in several industrial clusters. One of the clusters was located in Pesalakan, Adiwerna Village, Adiwerna District, Tegal Regency. As of 2018, the cluster had 229 tofu industrial units. The Ministry of Environment of the Republic of Indonesia, in co-operation with the Deutsche Gesellschaft für Technische Zusammenarbeit-GTZ of Germany, made an effort to improve economic and environmental performance nearby these SMEs by an eco-efficiency program, which promoted cleaner production. The cleaner production application in the SMEs took place by a mentoring strategy. One of the targets of the program was SMEs in Pesalakan, Adiwerna Village, Adiwerna District, Tegal Regency [4]. The tofu industry in Pesalakan had been practiced more than twenty years

\footnotetext{
* Corresponding author: sykfisip_undip@yahoo.co.id
} 
by traditional technology and poor business administration. The efficiency potential in the cleaner production application was the reduction of carbon dioxide pollution and increasing economic benefits. But, the local tofu makers did not sustain their cleaner production practices and retained the traditional production pattern.

\section{Theoretical Background}

There are seven key elements to develop eco-efficiency, i.e.: material use reduction, energy use reduction, pollution reduction, material recycling extension, maximizing renewable natural resources, prolonging product use, and increasing service intensity [2]. The eco-efficiency concept is a combination of economic and ecological efficiencies, which is formulated as the "value of goods or services divided by environmental impact." There are reasons for choosing the eco-efficiency operation measurement, i.e.: tracing and documenting its performance, identifying cost-saving and benefit, identifying and prioritizing opportunities to develop [10, 11], and utilisation of key instruments for change to estimate environmental cost and energy use as well as natural resources use $[11,12]$.

Three aspects can be identified as eco-efficiency indicators, as follows: (1) product/service value, with product volume, results with monetary rates (sales, benefit, etc.), and product/service functional aspects as parameters; (2) environmental influence in the making/providing goods or services process, with energy consumption, material consumption, and natural resources consumption (such as water), greenhouse gas emission, ozone-depleting emission, and non-product output as parameters; and (3) environmental influence adjacent to products/services, with recyclability, reusability, durability, safety/risk, package waste, energy consumption in product/service use, emission during use and disposal of product/service (loss of land, water, and air disturbance in the use and disposal/dumping of product/service), environmental impact due to product and service use itself as parameters [2]. For different businesses, some service indicators can also be measured by different parameters; and simple indicators are possibly insignificant for particular businesses. The NonProduct Output (NPO) parameter is widely used in developing the eco-efficiency application in Indonesia. The NPO itself has a great potential to increase efficiency because generally, the cost to produce the NPO is $10-30$ per cent.

Results from eco-efficiency studies prove different figures. Gossling et al. [13] report that tourism SMEs in Rockey Mountain National Park, Amsterdam, and France prove a low eco-efficiency rate of tourism SMEs. Vine et al. [14] find that (a) SMEs in Venezuela understand the environmental regulation but do not think it as an external force like customers demand towards environmental-friendly product or institutional force; (b) eco-economy adoption has not been acceptable as a driving force to improve competitiveness to be adopted as an environmental strategy to help reduce the cost and prevent sanction and negative image of the business; (c) eco-efficiency practices to be applied include recycle and reuse, in particular on packing materials, but they have not applied the other practices; and (d) food and chemical industries have a high eco-efficiency index, and plastic and lumber industries have a low ecoeconomic index. Iwata and Okada [15] in their study on the cost performance of the Japanese companies find that the waste management does not have a significant impact on financial performance and greenhouse gas emission reduction in the long-term significantly help improve the companies' financial performance.

In developing countries, at micro-, small-, and medium-scales running the dirty sector economic consideration likely becomes the priority than environmental impact consideration. Some studies have made an effort to answer the question of "pressure" on the SMEs in developing countries to obey the regulation in the environmental sector that will increase unemployment and poverty rates. Dasgupta [8] finds that in the mid-90s India, the government suddenly and "dramatically" applied regulations in environmental sectors towards small industrial clusters running the dirty sector. This effort increase unemployment and poverty in urban areas. Frijin and van Villet [8] also find that the environmental standard for the small industries should have been loosened to obtain equality between local workers and the environment. On the other hand, Tendler [8] argues that some case studies suggest that the SMEs will be able to answer the challenges from new regulations, including environmental regulations, without suffering significant economic loss. Tendler adds that restructuring new regulations is a good process to open the possibility to the SMEs to become more efficient, high quality in product, and coping with new markets.

SMEs can not be let alone in overcoming the environmental problems due to their activities. They have limitations, which make them difficult to prevent and to overcome the environmental pollutions. These limitations are time-based [16] and resource-, knowledge-, and skill-based [16-18]. Difficulties become more apparent when the SMEs do not trust the use of regulations to improve their environmental performance [17]. The Netherlands has a long history of cleaner production by a time-consuming and well-premared process. The central and local governments play an active role as partners for the SMEs in the cleaner production application. There are two important roles played by both levels of government, i.e.: (a) regulating role, which deals with regulation setting and enforcement and business licensing; and (b) stimulating role, which relates to motivation boost, advice, and support to the SMEs [16]. 


\section{Research Methodology}

\subsection{Research Samples}

Samples were selected by a purposive method on the following considerations: production capacity, operation continuity, use of communal wastewater management installation facility, and experience in eco-efficiency education. The samples consisted of 6 (six) tofu industries; three using husk energy and 3 using sawdust energy; two with $24-40 \mathrm{~kg}$ of soybeans/day production capacity, two with $40-80 \mathrm{~kg}$ of soybeans/day production capacity, and two with $>80 \mathrm{~kg}$ of soybeans/day production capacity.

Table. 1. Number of Samples

\begin{tabular}{|c|c|c|}
\hline Sample & Soybean Capacity (Kg/Day) & Energy \\
\hline 1. & 24 & Husk \\
\hline 2. & 72 & Husk \\
\hline 3. & 105 & Husk \\
\hline 4. & 30 & Sawdust \\
\hline 5. & 77 & Sawdust \\
\hline 6. & 90 & Sawdust \\
\hline
\end{tabular}

\subsection{Research Variables}

This study consisted of three research variables, they are cleaner production practices and eco-efficiency, which was examined from sub-variables of product value with such parameters as tofu volume, sales rate, and environmental impact of tofu processing, energy consumption, soybean raw material consumption, water consumption, and non-product output.

\subsection{Technique of data collection and data analysis}

The data were collected by interviews, field observation, and measurement, and were subject to descriptive analysis. Using these data, the following formula applied to calculating the eco-efficiency [2]:

$$
\text { Ecoefficiency }=\frac{\text { product or service value }}{\text { Environmental Influence }}
$$

\section{Results and Discussion}

\subsection{Samples of cleaner production practices in the study}

Cleaner production practices the Pesalakan tofu clusters performed during the mentoring for the eco-efficiency replication in 2008 were as follows: boiling to prevent crater, accelerate the boiling point by covering the pan during the process, and use the kettle for cooking. To support the cleaner production, efforts such as better management of fuel, improvement of the production room, and maintenance of production equipment took place.
Of the six research samples, two units had applied the cleaner production by improving the boiling method with the covered pan to accelerate the boiling point (sample No.5) and to remove the crater and to insert the dough into the pan after the water was boiled (samples No.4 and No.5).

The efficiency that could be obtained by boiling the water in the covered pan using sawdust energy was 31$37 \%$ with time efficiency of $27-30 \%$, whereas using husk energy was $35-37 \%$ with time efficiency of 207 $29 \%$. The crater volume was $0.33-1.14$ per cent of the production capacity. Even though small in percentage, the craters would cause the tofus to smell burned. The tofu unit owners knew the potential of environmental pollution from their activities during the eco-efficiency replication program. During this, they were mentored so that their activities were always under control.

The boiling method went back to the traditional process because most workers were more convenient and efficient in doing their jobs with it.

\subsection{Eco-efficiency rate}

\subsubsection{Economic performance to achieve}

The economic performance to be achieved was reflected by benefit earned and loss suffered by the business units. Of the six samples, all earned the benefits range of 9$29 \%$. The highest percentage of benefit was earned by sample No.4 with the highest production capacity, i.e. $35,280 \mathrm{~kg}$ soybeans/year. Whereas, sample No.2 had the lowest rate $(24,192 \mathrm{~kg}$ soybeans/year), ranked fourth in capacity rate.

Table. 2. Annual Business Benefit/Loss per of the SMEs

\begin{tabular}{|c|c|c|r|r|}
\hline $\begin{array}{c}\text { Sa } \\
\text { m- } \\
\text { ple }\end{array}$ & $\begin{array}{c}\text { Sales } \\
\text { (Thousand } \\
\text { Rp) }\end{array}$ & Cost (Rp) & Benefit (Rp) & $\begin{array}{c}\% \\
\text { Benefit }\end{array}$ \\
\hline 1 & $108,763,2$ & $82,367,864.26$ & $26,395,335.74$ & 24.27 \\
\hline 2 & 336,060 & $304,081,368.35$ & $31,978,631.65$ & 9.52 \\
\hline 3 & 518,300 & $449,316,153.06$ & $68,983,846.94$ & 13.31 \\
\hline 4 & 174,040 & $122,425,990.85$ & $51,614,009.15$ & 29.66 \\
\hline 5 & 381,100 & $362,228,073.66$ & $54,871,926.34$ & 14.40 \\
\hline 6 & 499,640 & $390,848,235.81$ & $108,791,764.19$ & 21.77 \\
\hline
\end{tabular}

The NPO cost percentage, or "non-associated" costs to the end-year production, but to the side-product and waste ranged $10-18 \%$. 
Table. 3. The NPO Percentage agaist Annual Direct Production Cost of the Research Samples

\begin{tabular}{|c|c|c|c|c|}
\hline $\begin{array}{l}\mathrm{S} \\
\mathrm{a} \\
\mathrm{m} \\
\mathrm{p} \\
1 \\
\mathrm{e}\end{array}$ & $\begin{array}{l}\text { Annual } \\
\text { Producti } \\
\text { on } \\
\text { Capacity } \\
\text { (Kg) }\end{array}$ & $\begin{array}{l}\text { NPO Cost } \\
\text { (Rp) }\end{array}$ & $\begin{array}{c}\text { Direct } \\
\text { Production } \\
\text { Cost }(\mathrm{Rp})\end{array}$ & $\begin{array}{c}\text { NPO } \\
\text { Cost } \\
\text { against } \\
\text { Total } \\
\text { Annual } \\
\text { Direct } \\
\text { Producti } \\
\text { on Cost } \\
(\%)\end{array}$ \\
\hline 1 & 8,064 & $15,169,443.12$ & $82,740,867.76$ & 18.33 \\
\hline 2 & 10,080 & $18,224,713.87$ & $115,873,990.13$ & 15.28 \\
\hline 3 & 24,192 & $33,826,702.57$ & $284,318,057.18$ & 11.90 \\
\hline 4 & 25,872 & $34,717,226.06$ & $316,148,073.67$ & 10.98 \\
\hline 5 & 30,240 & $45,298,133.07$ & $369,008,235.81$ & 12.28 \\
\hline 6 & 35,280 & $54,169,561.54$ & $416,870,939.08$ & 12.99 \\
\hline
\end{tabular}

Source: analysis result, 2018
Knowledge about NPO cost in the production became important because the potential of efficiency effort could affect the economic and environmental performance from the NPO cost. The higher the NPO cost, the worse the business; the lower the NPO cost, the better the business. The highest percentage of NPO cost belonged to sample No.1, whereas the lowest to sample No.4; both had lower capacity rates than the other samples. Samples with the lowest NPO cost percentage practiced cleaner production (placing tofu dough when the water began to boil so no craters were developed); whereas sample No.5, albeit practicing cleaner production (cooking in a covered pan and pouring the dough after the water were boiled) had the third-lowest NPO cost percentage. From the NPO cost percentage, each process of the whole production process, the highest percentage took place during boiling, filtering, and coloring processes. Therefore, the potential of the efficiency lied in these three processes.

Table. 4. Annual NPO Cost Percentage against Production Process Stage of the SMEs

\begin{tabular}{|l|r|r|r|r|r|r|}
\hline Process Stage & Sample-1 & \multicolumn{1}{|c|}{ Sample-2 } & Sample-3 & Sample-4 & Sample-5 & Sample-6 \\
\hline Dipping & 0.99 & 1.06 & 1.42 & 1.35 & 1.35 & 2.45 \\
\hline Washing & 0.95 & 0.94 & 1.12 & 1.31 & 1.31 & 2.30 \\
\hline Milling & 10.83 & 0.77 & 0.99 & 1.11 & 1.11 & 2.08 \\
\hline Boiling & 34.10 & 50.71 & 56.17 & 48.53 & 48.53 & 42.26 \\
\hline Filtering & 25.14 & 24.29 & 18.33 & 27.31 & 27.31 & 34.19 \\
\hline Coagulat-ing & 4.06 & 5.32 & 5.86 & 7.32 & 7.32 & 7.12 \\
\hline $\begin{array}{l}\text { Packing, } \\
\text { pressing }\end{array}$ & 2.23 & 0.41 & 0.40 & 0.54 & 0.54 & 0.52 \\
\hline Ngocet & 4.16 & 2.27 & 4.25 & 3.10 & 3.10 & 2.30 \\
\hline Coloring & 17.54 & 14.23 & 11.46 & 9.43 & 9.43 & 6.78 \\
\hline Salting & 0.00 & 0.00 & 0.00 & 0.00 & 0.00 & 0.00 \\
\hline Total (\%) & 10.00 & 100.00 & 100.00 & 100.00 & 100.00 & 100.00 \\
\hline
\end{tabular}

Sources: Calculation Result, 2018

\subsubsection{Environmental performance to achieve}

The environmental performance was reflected by the eco-efficiency rate to be achieved. This eco-efficiency calculation was based on business benefit and $\mathrm{CO} 2$ emission of fuel consumption. The lowest $\mathrm{CO} 2$ emission happened to sample No.4 with less production capacity rate than the other four samples and no-crater boiling method.

With reference to the emission factor of $1 \mathrm{~kg}$ of husks, $\quad 1.2 \mathrm{~kg}$ of $\mathrm{CO} 2$ equivalent (www.scribd.com/doc/3085035/Chemical Analysis of Rice-Husk -Ash) and the emission factor of $1 \mathrm{~kg}$ of wood is $3,113 \mathrm{~kg} \mathrm{CO} 2$ equivalent (Perry: Chemical Engineering Hand Book) is the same as the wood emission factor. And based on the use of SME electricity, it can be calculated emissions of electricity usage in production. Every $1 \mathrm{kWh}$ of electricity emits $0.891 \mathrm{~kg}$ of CO2 (Minister of Energy and Mineral Resources Decree No. 3783/21 / 600.5 / 2008). Then the $\mathrm{CO} 2$ emissions of the fuel used in the study sample are as follows.
Table. 5. $\mathrm{CO}_{2}$ Emission (in ton/year)

\begin{tabular}{|c|c|c|c|}
\hline Sample & $\begin{array}{c}\mathrm{CO}_{2} \\
\text { emission } \\
\text { from fuel } \\
\text { consumption }\end{array}$ & $\begin{array}{c}\mathrm{CO}_{2} \\
\text { emission } \\
\text { from } \\
\text { electricity } \\
\text { consumption }\end{array}$ & $\begin{array}{c}\text { Total of } \\
\mathrm{CO}_{2} \\
\text { emission }\end{array}$ \\
\hline 1 & 21.773 & 0.329 & 22.102 \\
\hline 2 & 66.528 & 1.108 & 67.636 \\
\hline 3 & 86.486 & 1.677 & 88.163 \\
\hline 4 & 52.298 & 0.494 & 52.792 \\
\hline 5 & 100.413 & 1.168 & 101.581 \\
\hline 6 & 143.821 & 1.537 & 145.358 \\
\hline
\end{tabular}

Source: Analysis Result, 2018

Whereas, sample No.5 with the fifth production rate and the eco-efficiency practice in its production emitted the second highest $\mathrm{CO}_{2}$. In this case, the eco-efficiency practice was not evidenced in the $\mathrm{CO}_{2}$ emission from the production process. Results obtained from the observation of the NPO parameter in the six samples found an idle source in the production process. The idle source is energy burning during the waiting time of a process from one phase to another. In the samples No.2 and No.5 there were sometimes waiting times from one 
cooking process to another, which needed 5-8 minutes when the fuel burns.

Table. 6. Eco-efficiency Rate of SMEs

\begin{tabular}{|c|c|c|c|}
\hline $\begin{array}{c}\text { Sam } \\
\text { ple }\end{array}$ & $\begin{array}{c}\text { Annual Operation } \\
\text { Benefit (Rp) }\end{array}$ & $\begin{array}{c}\text { Total } \mathrm{CO}_{2} \\
\text { emission } \\
\text { (ton/year) }\end{array}$ & $\begin{array}{c}\text { Eco-efficiency } \\
\text { rate }(\mathrm{Rp} / \text { ton } \\
\mathrm{CO}_{2} \text { ) }\end{array}$ \\
\hline 1 & $26,395,335.74$ & 22.102 & $1,194,251.01$ \\
\hline 2 & $31,978,631.65$ & 67.636 & $472,804.89$ \\
\hline 3 & $68,983,846.94$ & 88.163 & $782,458.06$ \\
\hline 4 & $51,614,009.15$ & 52.792 & $977,686.19$ \\
\hline 5 & $54,871,926.34$ & 101.581 & $540,179.03$ \\
\hline 6 & $108,791,764.19$ & 145.358 & $748,440.16$ \\
\hline
\end{tabular}

Source: Analysis Result, 2018

The highest eco-efficiency rate of the samples was obtained by sample No.1. This sample was a small capacity unit (24 kg soybeans/day) with four-time cooking periods using two workforces. Whereas, sample No.2 had the worst eco-efficiency rate. This sample had a capacity rate of $77 \mathrm{~kg}$ soybeans/day with five workforces but had a quite high idle source. The delay of the filtering process was due to the unfinished tofu packing process, while the boiling continued. The observation found that the samples lacked packing skilled workforces; and the work tables were designed for two persons.

The reduction of energy use was an important thing to develop the eco-efficiency for the tofu small industries in Pesalakan Clusters to reduce pollution. Some factors that determined the successful eco-efficiency practice included leadership, vision, culture, and managerial facilities and infrastructures [1]. On-time work system for the tofu makers was unlikely evidenced even though the business owners knew the potential pollution; they prioritized how to get the things done. Limited time [16], limited resources, knowledge, and skill [16-18] became characteristics of the tofu industry in Pesalakan. Poor business administration created difficulty in tracing the performance due to the absence of business documentation; so that no identification and opportunities to develop the business efficiency. Of the six samples, one unit ran without the intensive involvement of the owner during the production process. Poor monitoring function was due to over-trust towards the production output to the skillful workers; however, this might have not been overlooked because the core managerial functions include monitoring; i.e. operational monitoring [19] and quality monitoring [20].

\section{Conclusion and Recommendation}

NPO cost for the tofu industry in Pesalakan ranged 1018 per cent of the total production cost; quite significant for efficiency. The cleaner production practices that could be applied included energy reduction through water boiling in covered pan and crater removing through the tofu raw materials dough into the water when the water began to boil. Such practices would give significant-efficiency when performed. SMEs could not be let alone in coping with environmental problems. The government and community had to play their roles to improve the environmental performance of the SMEs.

\section{References}

1. R.V. Berkel, The International Handbook on Environmental Technology Management.: Cleaner and production (edited by D. Marinova, Annandale, J. Phillimore), EEP, Inc, Northampton, Massachusetts, 67-92 (2006)

2. H.A. Verfaillie, R. Bidwell, Measuring Ecoefficiency, a Guide to Reporting Company Performance, World Business Council for Sustainable Development Geneva (2000)

3. OECD, Small and Medium Enterprise Outlook, Paris: Organization for Economic Cooperation and Development (2002)

4. Anonim, Sembilan Langkah Pengelolaan Lingkungan Terpadu di Klaster: Panduan Integrasi Produksi Bersih dan Pengelolaan Air Limbah di Klaster Industri Kecil dan Menengah, Kementerian Negara Lingkungan Hidup Republik Indonesia. Jakarta (2009)

5. Kompas Wednesday, 17 February 2016

6. A. Husin, Pengolahan Limbah Cair Industri Tahu Dengan Biofltrasi Anaerob Dalam Reaktor FixedBed, Tesis, Universitas Sumatera Utara, Medan. (2008)

7. PPBN, Panduan Penerapan Produksi Bersih Industri Tahu. Jakarta (2006)

8. A. Blackman, Introduction Small Firms and Environment. Small Firms and the Environment in Developing Countries, Collective Impacts Collective Action, Resources for the Future. (ed.), Washington DC. USA. (2006)

9. S.X. Zeng, X.H. Meng, R.C. Zeng, C.M. Tam, V.W.Y. Tam, T. Jin, How environmental management driving forces affect environmental and economic performance of SME: a study in Northern China district, Journal of Cleaner Production. 19, 1426-575 (2011)

10. C. Holliday, S. Scmidheiny, P. Watts, Walking the Talk: The bUsiness Case for Sustainable Development, Sheffield. Greenleaf Publishing Limites (2002)

11. F. Lysrstedt, Measuring Eco-efficiency by a LCC/LCA ratio, an evaluation of its aplicability a case study at $A B B$, Centre for Environmental Assessment of Product and Material Systems, Chalmers University of Technology. Sweden. (2005)

12. R.D. Andraca, K. McCready, Internalizing Environmental Costs to Promote Eco-efficiency, The Business Council for Sustainable Development. Geneva (1994)

13. S. Gossling, P. Peeters, J.P. Ceron, G. Dubois, T. Patterson, R.B. Richardson, The eco-efficiency of tourism, Ecological Economics J. 54, 417-434 (2005) 
14. M.B.F. Vine, T.G. Navarro, S.F.C.Rizo, Ecoefficiency in the SME's of Venezuela.Current status and future perspectives, Journal of Cleaner Production 18, 736-746 (2010)

15. H. Iwata, K. Okada, How does environmental performance affect financial performance? Evidence from Japanese manufacturing firms, Cecological Economics J. 70, 1691-1700 (2011)

16. M. Gombault, S. Versteege, Cleaner production in SME through a partneship with (local) authorities: successes from the Netherlands, Journal of Cleaner Productions 7, 249-261 (1999)

17. R. Hillary, Small and Medium-Sized Entrepririses and Environment: Bisnis Imperatives. Sheffield: Greenleaf Publishing (2000)

18. J. Vernon, S. Essex, D. Pinder, K. Curry, The greening of tourism micro-business: outcomes of focus group investigations in South East Cornwall, Business and the Environment 12, 49-69 (2003)

19. H. Prasetya, F. Lukiastuti, Manajemen Operasi. Graha Ilmu Yogyakarta. (2009)

20. J. Heizer, B. Render, Manajemen Operasi. Penerbit Salemba Empat. Jakarta 11 (2014) 